\title{
AS FACETAS DA ALFABETIZAÇÃO NOS CURSOS DE PEDAGOGIA: desafios para a formação do professor
}

\author{
Simone Regina Manosso Cartaxo \\ Universidade Estadual de Ponta Grossa - UEPG \\ Giselle Cristina Smaniotto \\ Universidade Estadual de Ponta Grossa - UEPG
}

Maria Iolanda Fontana Universidade Tuiuti do Paraná - UTP

\begin{abstract}
Resumo
O objetivo deste estudo é analisar as facetas da alfabetização indicadas em programas de cursos de Pedagogia do Brasil, a fim de discutir as ênfases, as lacunas e os desafios desta área do conhecimento para a consistente e eficaz atuação profissional. A metodologia desta pesquisa pautou-se na coleta e análise de 97 ementas e 68 bibliografias localizadas em 70 Projetos Pedagógicos de Curso. A análise das ementas revelou a priorização das facetas pedagógica e sociocultural e a análise das bibliografias o predomínio de obras que fundamentam o estudo das facetas sociocultural $\mathrm{e}$ psicológica/psicolinguística. A presença da perspectiva sociocultural entre os conteúdos e as bibliografias das disciplinas significa um avanço. No entanto, os programas dos cursos apresentam lacunas em relação à base epistemológica teórico-prática referente ao ensino e à aprendizagem da leitura e da escrita e aos processos sociais que influenciam a alfabetização. Conclui-se que o desafio ético-político a ser materializado na formação de professores alfabetizadores demanda o estudo inter-relacionado das multifacetas do conhecimento científico-pedagógico para o enfrentamento da desigualdade educacional, que não tem garantido a alfabetização como um direito humano.
\end{abstract}

Palavras-chave: Curso de Pedagogia, formação inicial, professor alfabetizador, alfabetização e letramento.

\begin{abstract}
The objective of this study is to analyze the facets of literacy indicated in programs of Pedagogy courses in Brazil, in order to discuss the emphases, the gaps and the challenges of this area of knowledge for the consistent and effective professional performance. The methodology of this research was based on the collection and analysis of 97 menus and 68 bibliographies located in 70 Pedagogical Projects of Course. The analysis of the menus revealed the prioritization of the pedagogical and sociocultural facets and the analysis of bibliographies the predominance of works that base the study of the sociocultural and psychological/psycholinguistic facets. The presence of the socio-cultural perspective between the contents and the bibliographies of the disciplines means an advance. However, the course programs present shortcomings in relation to the theoreticalpractical epistemological base regarding teaching and learning of reading and writing and to the social processes that influence literacy. It is concluded that the ethical-political challenge to be materialized in the training of literacy teachers demands the interrelated study of the multi-facets of scientific-pedagogical knowledge to address educational inequality that has not guaranteed literacy as a human right.
\end{abstract}

Key words: Pedagogy course, initial training, literacy teacher.

ISSN 1645-1384 (online) www.curriculosemfronteiras.org

http://dx.doi.org/10.35786/1645-1384.v20.n3.25 


\section{Introdução}

As discussões sobre a formação do alfabetizador, na formação inicial e continuada, têm enfatizado que as práticas de alfabetização devem ocorrer na perspectiva do(s) letramento(s), ou seja, o alfabetizar letrando. Tanto o conceito de alfabetização como o conceito de letramento dizem respeito às habilidades de ler e escrever, entretanto, o que especifica a alfabetização é a aquisição do sistema alfabético-ortográfico da escrita e o que especifica o letramento é o seu caráter social.

Os conceitos de alfabetização e letramento não são intercambiáveis, pois denotam processos distintos, embora sejam indissociáveis (SOARES, 2004). Alfabetização é a "“ação de alfabetizar, de ensinar a ler e escrever', que leva o aprendiz a conhecer o alfabeto, a mecânica da escrita/leitura, a se tornar alfabetizado." (ROJO, 2009, p. 44). Durante o processo de alfabetização, o sujeito, individualmente, conhece o funcionamento do sistema alfabético-ortográfico de escrita (estabelece relação fonema-grafema, decodifica, codifica...) e passa a dominá-lo, o que permite que leia e escreva. Todavia, dominar o sistema de escrita não é garantia de inserção e interação nas diferentes práticas sociais que envolvem a escrita. Para dar conta dessa perspectiva social, surge o termo-conceito de letramento, que "não é pura e simplesmente um conjunto de habilidades individuais; é o conjunto de práticas sociais ligadas à leitura e à escrita em que os indivíduos se envolvem em seu contexto social" (SOARES, 1998, p. 72).

Ao pensarmos a formação inicial do alfabetizador, considerando o contexto de formação no curso de Pedagogia, conforme Pimenta et al. (2020), é necessário contemplar essas especificidades, e ter em mente que o processo de alfabetizar letrando é complexo e multifacetado, o que implica conhecimentos de diferentes áreas para uma formação de consistente base teórica e interdisciplinar. Desde a década de 80, Soares vêm destacando as diferentes facetas ${ }^{1}$ da alfabetização, que se alternam a depender da ênfase dos pressupostos teóricos que influenciam o processo de alfabetização em cada época. A autora apresenta algumas dessas facetas: psicológica, psicolinguística, sociolinguística, linguística (1985, $2000^{2}$ ); sociológica (2000); linguística e psicológica acrescida das facetas do letramento (2004); o conceito de letramento dos pontos de vista antropológico, linguístico, psicológico e pedagógico (2010); e agrupando algumas facetas, em seu livro mais recente, ela propõe três facetas que contemplam as especificidades do alfabetizar e do letrar: a linguística, a interativa e a sociocultural (2016). As especificidades de cada faceta serão apresentadas no próximo tópico.

Essas facetas da alfabetização têm relação com paradigmas teóricos que foram se constituindo historicamente. Soares (2004) afirma que, nas últimas décadas, assistimos a mudanças de paradigmas teóricos no campo da alfabetização: o paradigma behaviorista, dominante nas décadas de 1960 e 1970, substituído na década de 1980 por um paradigma cognitivista, o qual avança, na década de 1990, para um paradigma sociocultural. Para a autora, se a transição da teoria behaviorista para a teoria cognitivista representou realmente uma mudança radical de paradigma, a transição da teoria cognitivista para a perspectiva 
sociocultural pode ser interpretada, antes, como um aprimoramento do paradigma cognitivista, do que propriamente como uma mudança paradigmática.

No contexto dos paradigmas teóricos que foram se constituindo e das diferentes facetas da alfabetização, compreendemos, em acordo com Mortatti (2006) e Soares (2016), que os movimentos envolvidos tanto na produção de novas bases teóricas como em propostas metodológicas sempre almejaram superar o problema do fracasso da aprendizagem da leitura e da escrita.

Associadas às facetas da alfabetização mencionadas por Soares (1985, 2004, 2010, 2016) e Soares e Maciel (2000), recorremos aos conhecimentos necessários para a formação inicial, na licenciatura em Pedagogia, conforme discutem os autores Saviani (2011); Scheibe (2007); Gatti (2010); Romanowski (2016), a fim de refletirmos sobre a formação do professor alfabetizador neste curso.

Entendemos que a formação inicial de professores, numa concepção sócio-histórica ${ }^{3}$, precisa abranger conhecimentos nas dimensões profissional, política e epistemológica para que o profissional da educação compreenda a totalidade do trabalho docente, ancorado na relação teoria-prática e realize a práxis educativa emancipadora.

Neste sentido, os conhecimentos se constroem a partir das experiências com estudos, pesquisas e diálogos com a escola e com os pares envolvidos, desde os primeiros anos de formação. Alguns tipos de conhecimentos necessários à docência necessitam ser enfatizados na formação inicial, como tensionado por Nörnberg et al. (2019), pois para saber ensinar é preciso ter o conhecimento científico e filosófico e estabelecer vínculos com a prática pedagógica em seu sentido amplo, ou seja, como processo intencional e sistematizado de trabalho e como dimensão da prática social transformadora.

A unidade entre licenciatura e bacharelado nos cursos de Pedagogia, conforme explica Scheibe (2007, p. 59-60), "relaciona-se diretamente com a ideia da docência como fulcro do processo formativo dos profissionais da educação, dando suporte conceitual e metodológico para a união entre teoria e prática".

A ênfase nos conteúdos práticos relativos aos métodos de alfabetização marcou a formação inicial de professores alfabetizadores, realizada principalmente na escola Normal, nos cursos de magistério em nível médio. A aprovação das diretrizes do curso de licenciatura em Pedagogia, no ano de 2006, estabeleceu como campo de atuação do pedagogo a docência na educação infantil e nos anos iniciais do ensino fundamental, níveis da educação básica, nos quais se inicia o processo de alfabetização. O currículo da graduação em Pedagogia incluiu o estudo de conteúdos básicos articuladores da relação teoria e prática, referente aos contextos: histórico e sociocultural, da educação básica e do exercício profissional. A docência passa a ser a base da formação do pedagogo e os conhecimentos didáticos suscitam a unidade teoria e prática e a reflexão sobre a realidade educacional brasileira.

Diante do reconhecimento da complexidade do processo de formação do professor, este estudo tem o objetivo de analisar as facetas da alfabetização ${ }^{4}$ indicadas em propostas de ensino de cursos de Pedagogia do Brasil, considerando que este é o lócus de formação do professor alfabetizador, a fim de discutir as ênfases, as lacunas e os desafios desta área do conhecimento para a consistente e eficaz atuação profissional. Assim, buscamos responder 
às indagações: Quais facetas da alfabetização têm sido priorizadas na formação inicial da licenciatura em Pedagogia? Quais lacunas são identificadas e quais são os desafios a serem transpostos para que a formação do professor alfabetizador contemple a visão multifacetada da alfabetização que o capacite teórica e metodologicamente para ensinar e enfrentar a ação educativa escolar em sua totalidade de determinações?

$\mathrm{O}$ desenvolvimento desta pesquisa é de abordagem qualitativa e pautou-se na coleta e análise dos documentos: Projetos Pedagógicos de Cursos (PPCs) de Pedagogia, ementas e bibliografias disponíveis nos sites das universidades públicas e privadas e dos Institutos Federais, de modalidade presencial, do Brasil.

A pesquisa foi realizada em $2017^{5}$ no portal das 199 universidades brasileiras e dos 38 Institutos Federais de Educação, Ciência e Tecnologia. Foram encontrados 70 PPCs de Licenciatura em Pedagogia e 97 ementas de componentes curriculares relativos à alfabetização, acompanhadas das bibliografias. Os 70 PPCs disponibilizados nos sites correspondem a 50 universidades públicas, 17 universidades privadas e 3 Institutos Federias de Educação, Ciência e Tecnologia. Após a organização inicial dos documentos, foi constatado que a maioria das instituições públicas disponibiliza o PPC em seu portal, e a maioria das instituições privadas disponibiliza apenas as ementas dos componentes curriculares que ofertam no curso.

O recorte realizado neste estudo priorizou o nome dos componentes curriculares (títulos das disciplinas), o conteúdo das ementas e as bibliografias, possibilitando a categorização e análise de conteúdo, conforme Bardin (2010). As categorias de análise foram definidas por meio da classificação dos elementos constitutivos do conjunto de ementas e bibliografias, por diferenciação de termos, seguido de reagrupamentos baseados em recorrências e analogias, considerando-se os conceitos das múltiplas facetas da alfabetização.

No próximo tópico, apresentaremos a relação entre os conceitos de alfabetização e letramento e suas facetas, fundamentados em estudos já realizados por Soares. Na sequência, discutiremos a formação inicial do professor alfabetizador no curso de Pedagogia com o foco na problematização das fragilidades e em demandas políticas e didático-pedagógicas para formação do docente alfabetizador. Por fim, apresentamos a análise das ementas e das bibliografias, de modo a destacar as facetas que têm sido priorizadas, as facetas secundarizadas, as lacunas e demandas na formação para o ensino da alfabetização no curso de Pedagogia.

\section{Alfabetização e letramento e suas facetas}

Os conceitos de alfabetização e letramento, no Brasil, caminham juntos. Soares conclui, após análise dos conceitos de alfabetização implícitos nos censos demográficos brasileiros, que, ao longo das décadas, houve uma progressiva extensão do conceito de alfabetização em direção ao conceito de letramento: "saber ler e escrever em direção ao ser capaz de fazer uso da leitura e da escrita." (SOARES, 2004, p. 7). A autora observa também que, na produção acadêmica brasileira das décadas de 80 e 90, alfabetização e letramento estão quase sempre 
associados. O termo letramento surgiu em meados da década de 1980, em diferentes partes do mundo, diante da necessidade de nomear as práticas sociais de leitura e escrita que extrapolam o domínio do sistema de escrita. Soares (2004) explica que o termo passou a ser utilizado nos países desenvolvidos - illettrisme (na França), literacia (em Portugal) - para nomear um fenômeno diferente do da alfabetização, pois embora a população já estivesse alfabetizada, não dominava habilidades para uma participação efetiva nas práticas sociais e profissionais mediadas pela escrita. Entretanto, no Brasil ${ }^{6}$, o que se percebeu, à época, é que os conceitos de alfabetização e letramento "se mesclam, se superpõem, se confundem", nas palavras da autora, visto que a preocupação com as habilidades para o uso da leitura e da escrita tiveram sua origem vinculada à aprendizagem inicial da escrita, questionando-se o conceito de alfabetização.

Ressaltamos que essa distinção é relevante no contexto desta pesquisa porque, embora os professores formados nos cursos de Pedagogia e que atuam nos anos iniciais do Ensino Fundamental sejam responsáveis pelo ensino do funcionamento do sistema de escrita, proporcionando aos alunos(as) a alfabetização, esse processo, segundo orientações dos documentos oficiais ${ }^{7}$ como os Parâmetros Curriculares Nacionais e as Diretrizes Curriculares Nacionais para o Ensino o Fundamental de nove anos, deve acontecer na perspectiva do letramento.

Ou seja, as práticas de leitura e escrita vivenciadas pela criança durante o processo inicial de apropriação do sistema de escrita precisam ser práticas reais e autênticas de uso da língua, mesmo que estejam, na escola, sendo levadas a efeito por meio de processos de didatização. Isto quer dizer que os textos lidos e/ou produzidos não devem ser textos criados exclusivamente para se ensinar a ler e a escrever, tais como os textos cartilhescos, que apresentam palavras e sequências de frases desvinculadas de um contexto, gerando artificialidade e ambiguidades, mas textos de gêneros discursivos que façam parte de práticas sociais de diferentes esferas, tais como parlendas e cantigas presentes nas brincadeiras infantis (ou para resgate cultural dessas brincadeiras), poesias, pequenas narrativas da literatura infantil, lista de compras e de convidados para um aniversário, convites, rótulos de produtos utilizados em casa, entre tantos outros utilizados no dia a dia. Dessa maneira, a criança aprenderá a ler e escrever para participar e interagir nas práticas cotidianas mediadas pela escrita, sendo, em certos momentos, destinatária e, em outros, autora desses textos.

Ao definir letramento, Soares explica que há diferentes conceitos, a depender da perspectiva que se assume: antropológica, linguística, psicológica ou pedagógica. Do ponto de vista linguístico, os estudos focalizam as diferenças entre a língua oral e a língua escrita, e o letramento é "uma palavra que remete a aspectos linguísticos, psicolinguísticos e sociolinguísticos das práticas de escrita" (SOARES, 2010, p. 57). Ainda segundo a autora, na perspectiva psicológica, o letramento é entendido como um processo cognitivo de compreensão e produção de textos escritos. Já na abordagem antropológica, letramento são as práticas sociais de leitura e escrita vinculadas a certa cultura e permeadas por ideologia e poder.

No Brasil, é na perspectiva pedagógica que a palavra e o conceito de letramento são introduzidos, por sua aproximação com o conceito de alfabetização, no entendimento de que, 
além de adquirir o sistema alfabético-ortográfico e suas convenções, o indivíduo deveria ser inserido nas práticas sociais da língua escrita. Essa é, ainda hoje, a perspectiva dominante nos estudos e nas políticas educacionais no Brasil.

Soares (2010) argumenta que faltam no Brasil estudos de caráter antropológico e que o fato de a perspectiva pedagógica predominar nas pesquisas e políticas públicas brasileiras tem, pelo menos, três implicações, assim elencadas pela pesquisadora: 1) olhar majoritariamente avaliativo sobre os processos de alfabetização e letramento, com pouca reflexão sobre as causas e circunstâncias do baixo desempenho dos alunos; 2) necessidade de mais pesquisas de cunho etnográfico sobre a alfabetização e o letramento; 3) pesquisas que relacionem as práticas de leitura e escrita escolares com as práticas de letramento em outros contextos.

Compreendidas as especificidades dos conceitos de alfabetização e letramento e, ao mesmo tempo, suas relações de interdependência, passamos a abordar esse processo - o alfabetizar letrando - a partir das múltiplas facetas que o constituem. O que se pode notar nos estudos consultados é que, com o surgimento de outras ciências, principalmente a partir da década de 80, que passam a ter a alfabetização como interesse de estudos, ocorre a proposição de novas facetas da alfabetização.

No texto de 1985, Soares apresenta as facetas linguística, psicolinguística, sociolinguística e psicológica. No relatório da pesquisa "Alfabetização no Brasil: o estado do conhecimento", texto de 2000, Soares e Maciel, ao descreverem as produções acadêmicocientíficas (teses e dissertações) do período de 1961 a 1989, fazem um levantamento dos pressupostos teóricos que fundamentam os temas das pesquisas, de modo que tais perspectivas denotam as facetas mais privilegiadas em tais estudos. Os 219 estudos revelaram as seguintes facetas da alfabetização, por ordem de predominância: psicológica, pedagógica, linguística, psicolinguística, sociolinguística, sociológica. O tema alfabetização também foi objeto de estudos de áreas como a Educação Artística: Artes Plásticas e Música, a Audiologia, a Estatística, e, ainda, textos que conjugaram diferentes perspectivas teóricas. No texto de 2004, Soares menciona a faceta linguística ao se referir à necessária "reinvenção da alfabetização", postulando o resgate do ensino explícito do objeto linguístico, e a faceta psicológica, que teria provocado, devido a equívocos, a "desinvenção da alfabetização"; além de apresentar a necessidade de se agregar à alfabetização as práticas sociais de leitura e escrita - o letramento. Já no trabalho de 2016, a autora agrupa algumas categorias apresentadas no texto de 1985 à faceta linguística (a psicolinguística e a sociolinguística), tendo em vista que são disciplinas que compõem as ciências linguísticas. Essa faceta está relacionada ao conceito de alfabetização. Também propõe a faceta interativa, com foco nas questões de compreensão e produção de textos, que tem nas áreas da psicologia cognitiva e do desenvolvimento seus pressupostos teóricos. E por fim, a faceta sociocultural, que contempla as questões dos eventos e práticas de letramento. Soares relaciona as facetas interativa e sociocultural ao letramento.

Descrevemos, no Quadro 1, a seguir, cada uma das facetas apresentadas nos estudos mencionados, caracterizando o foco de estudo de cada uma. 
Quadro 1 - Facetas da alfabetização

\begin{tabular}{|c|c|}
\hline $\begin{array}{l}\text { FACETA } \\
\text { PSICOLÓGICA } \\
\text { Soares }(1985,2004,2016) \\
\text { Soares, Maciel }(2000)\end{array}$ & $\begin{array}{l}\text { Tem como foco os processos psicológicos considerados necessários como pré- } \\
\text { requisitos para a alfabetização e os processos por meio dos quais o indivíduo aprende } \\
\text { a ler e a escrever, bem como as habilidades de compreensão e produção de textos. } \\
\text { São exemplos os estudos sobre: relações entre inteligência (QI) e alfabetização; } \\
\text { relações entre aspectos fisiológicos e neurológicos e os aspectos psicológicos } \\
\text { (percepção do esquema corporal, estruturação espacial e temporal, discriminação } \\
\text { visual e auditiva, psicomotricidade etc.); disfunções psiconeurológicas (que dificultam } \\
\text { a aprendizagem da leitura e da escrita). Contempla, mais recentemente, as abordagens } \\
\text { cognitivas (Piaget, Emilia Ferreiro). }\end{array}$ \\
\hline $\begin{array}{l}\text { FACETA LINGUÍSTICA } \\
\text { Soares }(1985,2004,2016) \\
\text { Soares, Maciel }(2000)\end{array}$ & $\begin{array}{l}\text { Analisa o processo de alfabetização como um processo de natureza essencialmente } \\
\text { linguística: um processo de transferência da fala para a escrita, não só através da } \\
\text { construção das relações entre o sistema fonológico e o sistema ortográfico, mas também } \\
\text { através de transferências de natureza discursiva, semântica, morfossintática ( } 2000, \text { p. } \\
\text { 41). } \\
\text { Estudos sobre: consciência fonológica e fonêmica, identificação das relações fonema- } \\
\text { grafema, habilidades de codificação e decodificação da língua escrita, conhecimento e } \\
\text { reconhecimento dos processos de tradução da forma sonora da fala para a forma gráfica } \\
\text { da escrita. }\end{array}$ \\
\hline $\begin{array}{l}\text { FACETA } \\
\text { PSICOLINGUÍSTICA } \\
\text { Soares (1985) } \\
\text { Soares, Maciel (2000) }\end{array}$ & $\begin{array}{l}\text { Volta-se para a análise de problemas tais como a caracterização da maturidade } \\
\text { linguística da criança para a aprendizagem da leitura e da escrita, as relações entre } \\
\text { linguagem e memória, a interação entre a informação visual e não visual no processo } \\
\text { da leitura, a determinação da quantidade de informação que é apreendida pelo sistema } \\
\text { visual, quando a criança lê etc. }(1985, \text { p. } 22) \text {. }\end{array}$ \\
\hline $\begin{array}{l}\text { FACETA } \\
\text { SOCIOLINGUÍSTICA } \\
\text { Soares (1985) } \\
\text { Soares, Maciel (2000) } \\
\end{array}$ & $\begin{array}{l}\text { Considera a questão da interferência das diferenças culturais e dialetais no processo de } \\
\text { aquisição da leitura e da escrita (diferenças entre o sistema fonológico e ortográfico, } \\
\text { diferenças lexicais, morfológicas e sintáticas). }\end{array}$ \\
\hline $\begin{array}{c}\text { FACETA } \\
\text { SOCIOLÓGICA } \\
\text { Soares, Maciel (2000) }\end{array}$ & $\begin{array}{l}\text { A alfabetização é discutida à luz das condições sociais em que ocorre, analisando-se } \\
\text { sua determinação por fatores internos à escola e por mecanismos externos a ela (p. 41). } \\
\text { São exemplos de estudos: a investigação das relações entre condições sociais e } \\
\text { econômicas de vida e o rendimento em alfabetização; a adequação de cartilhas às } \\
\text { características e costumes da população que as utiliza, entre outros. }\end{array}$ \\
\hline $\begin{array}{c}\text { FACETA } \\
\text { PEDAGÓGICA } \\
\text { Soares, Maciel (2000) }\end{array}$ & $\begin{array}{l}\text { Trata a alfabetização na perspectiva dos fatores internos ao contexto escolar, } \\
\text { procurando desvelar as práticas pedagógicas da alfabetização, explicitar os } \\
\text { mecanismos e processos presentes no cotidiano da sala de aula, caracterizando } \\
\text { alfabetizandos e professores ou supervisores envolvidos no processo de alfabetização } \\
\text { (p. 40). }\end{array}$ \\
\hline $\begin{array}{c}\text { FACETA } \\
\text { SOCIOCULTURAL } \\
\text { Soares }(2004,2016)\end{array}$ & $\begin{array}{l}\text { Considera o contexto de práticas e usos sociais e culturais de leitura e escrita e sua } \\
\text { influência nas práticas escolares de alfabetização }(2016, \text { p. } 31) \text {. } \\
\text { Na prática: imersão das crianças na cultura escrita, participação em experiências } \\
\text { variadas com a leitura e a escrita, conhecimento e interação com diferentes tipos e } \\
\text { gêneros de material escrito }(2004, \text { p. } 15) \text {. }\end{array}$ \\
\hline
\end{tabular}

Fonte: Baseado em Soares $(1985,2004,2016)$ e Soares e Maciel (2000). Organização: as autoras

Além dessas facetas, Soares e Maciel (2000) mencionam os aspectos sociais e políticos que condicionam a alfabetização e que têm suscitado estudos sob as perspectivas sociológica, antropológica, econômica e política.

É importante lembrar que a conjunção entre todas as facetas mencionadas proporciona um processo de ensino e aprendizagem na alfabetização mais completo, logo, deveriam ser objeto de ensino na formação. A análise das ementas e das bibliografias podem revelar quais 
são as facetas mais enfatizadas na formação inicial do alfabetizador nos cursos de Pedagogia e quais são os desafios a serem enfrentados.

\section{A formação inicial dos professores para a alfabetização}

Na história da formação de professores, que emergiu no decorrer do século XIX, se configuraram dois modelos contrapostos para resolver os problemas de dois aspectos constitutivos do ato docente: o conteúdo e a forma. De um lado, está o modelo para o qual a formação de professores se esgota na cultura geral e no domínio específico dos conteúdos da área de conhecimento correspondente à disciplina que o professor irá lecionar; e, de outro lado, o modelo da formação pedagógica-didática (Saviani, 2011, p.8-9). O dilema, ainda em curso no Brasil, revela que, em ambos os modelos, o professor é formado pela somatória desses dois campos do conhecimento, mas com ênfases distintas, separados um do outro e pensados a partir de uma abstração.

Estudos de Romanowski (2016) constatam que, desde a década de 1980, os cursos de formação de professores têm centralizado mais nos conhecimentos dos conteúdos disciplinares do que nos conhecimentos pedagógicos. Gatti e Nunes (2009) verificaram, no curso de Pedagogia, um desequilíbrio na relação teoria-prática, isto é, uma ênfase nos fundamentos teóricos e poucos conteúdos referentes às disciplinas a serem ensinadas na educação básica. A exemplo dos conteúdos da alfabetização, assim como nas demais áreas de ensino, "são abordados de forma genérica ou superficial, sugerindo frágil associação com as práticas docentes" (Gatti, 2010, p. 1372).

No entanto, os resultados de pesquisas sobre a formação de professores têm pouca penetração e consideração na institucionalização dos cursos formadores como também na definição de uma política nacional específica para a formação inicial articulada, a qual se apresenta dispersa em leis, resoluções, portarias, pareceres, documentos orientadores etc. (Gatti, 2014, p.34).

A diretriz curricular para o curso de licenciatura em Pedagogia, Resolução CNE/CP $\mathrm{n}^{\circ}$ 1, de 15/05/2006 ${ }^{8}$, definiu a docência como eixo de formação com amplas atribuições ao pedagogo e com uma grande dispersão disciplinar. Esta configuração do curso criou tensões e impasses para o desenvolvimento curricular, fragilizando uma base comum formativa, principalmente em relação à atividade didática associada ao estudo das teorias que a fundamentam.

A Resolução CNE/CP de $n^{\circ} 2 / 2015^{9}$, que definiu diretrizes curriculares para a formação inicial em nível superior para os cursos de licenciatura e formação continuada, embora não tenha revogado a Resolução CNE/CP n¹/2006, faz a menção ao curso de Pedagogia apenas no Capítulo V, art.13, quando trata das orientações curriculares, por meio da garantia de base comum nacional, estabelecendo que, nesta licenciatura, "\$ $5-[\ldots]$ deverão preponderar os tempos dedicados à constituição de conhecimento sobre os objetos de ensino [...]" (BRASIL, 2015). A orientação valoriza as contribuições das áreas de ensino para o campo pedagógico, mas conforme alerta Pimenta et al. (2020, p.14), esse enfoque pode "materializar currículos 
com fortes fronteiras disciplinares, dada a ausência de clareza quanto ao critério de pertinência à formação de pedagogos(as) e enlaces com as dimensões teórico-práticas da educação". A atual Resolução CNE/CP n 2/2019, que institui a Base Nacional Comum para a Formação Inicial de Professores da Educação Básica (BNC-Formação) e revoga a Resolução CNE/CP n' 2/2015, retrocede a anterior ao enfatizar "prescrições metodológicas, como sugerem os paradigmas produtivistas embutidos em discursos de competências e boas práticas" (PIMENTA, 2020, p.16). Isso significa o fortalecimento da formação instrucional baseada em métodos e conteúdos dos objetos de ensino e a fragilização da formação pedagógica mais ampla, que tem como objeto a práxis educativa de perspectiva crítica para formação humana.

Conforme análise de Saviani (2011, p. 11-12), as Diretrizes Curriculares do Curso de Pedagogia são "muito restritas no essencial e assaz excessivas no acessório. A restrição diz respeito àquilo que configura a pedagogia como um campo teórico prático dotado de um acúmulo de conhecimentos e experiências resultantes de séculos de história". Segundo o autor, os acessórios são identificados na linguagem marcada por expressões da atualidade como conhecimento ambiental-ecológico, pluralidade de visões de mundo, interdisciplinaridade entre outros, que marcam um pluralismo eclético de diferentes perspectivas e aspectos da formação.

A Diretriz orienta, no art. $6^{\circ}$, que a estrutura do curso, entre outras indicações, contempla o estudo da Didática, de teorias e metodologias pedagógicas, de processos de organização do trabalho docente, o trabalho didático com conteúdos pertinentes aos primeiros anos de escolarização, relativos à Língua Portuguesa e demais ciências, na qual entendemos os conteúdos da alfabetização. Não há na diretriz nenhuma referência à alfabetização em sua especificidade e complexidade, o que permite, a critério das instituições de ensino superior, definir a abrangência dos estudos nesta área do conhecimento. Esta problemática tem instigado pesquisas sobre os conhecimentos selecionados para compor a formação do professor alfabetizador no curso de Pedagogia, a exemplo de Lotfi (2011), que estudou as matrizes curriculares dos cursos de Pedagogia do Estado de São Paulo, e de Piccoli (2015), que investigou as matrizes de cursos de universidades federais da Região Sul do Brasil.

Pretendemos, com o presente estudo, somar às investigações que problematizam a formação em alfabetização nos cursos de Pedagogia, com ênfase na análise das multifacetas do conhecimento científico-pedagógico que constituem esta área. Para tanto, fizemos a identificação de 97 ementas e 68 bibliografias dos 70 cursos de Pedagogia de instituições públicas e privadas do Brasil, considerando que as opções nestes cursos não são neutras e expressam uma concepção sobre a alfabetização e formação de professores.

\subsection{Análise das ementas}

A leitura das ementas foi realizada possibilitando uma codificação e categorização dos elementos pertinentes às diferentes facetas. Neste sentido, da leitura das 97 ementas emergiram conteúdos relacionados às várias facetas da alfabetização. 
Dentre as disciplinas consultadas nos cursos de Pedagogia, identificamos uma variedade de denominações com a priorização dos termos alfabetização e letramento: Alfabetização e Letramento; Fundamentos e Didática da Alfabetização; Processos de Aprendizagem de Leitura e Escrita; Teoria e Prática da Alfabetização; Alfabetização: teorias e métodos; Alfabetização e Consciência Fonológica; Psicogênese da Língua Escrita; Alfabetização e Linguística; Estágio Supervisionado (alfabetização e letramento: $1^{\circ}$ ao $3^{\circ}$ ano); Alfabetização e Letramento nos países da integração; Currículo e Alfabetização; Processos Pedagógicos da Alfabetização e do Letramento; Linguística Aplicada à Educação; Alfabetização e Letramento: linguagens e textualidades; Introdução à Linguística; Educação Básica no Brasil: alfabetização e letramento; Alfabetização e Avaliação; Alfabetização: oficina de material didático; Linguagem e Alfabetização; Escola, Alfabetização e Culturas da escrita; Alfabetização e Letramento: conteúdos e seu ensino; Prática de ensino e formação em Alfabetização e Letramento nos anos iniciais do Ensino Fundamental; Estudos teóricopráticos do ensino da Alfabetização e Letramento.

Uma breve análise dessas denominações indica a presença de diferentes facetas articuladas aos conteúdos das ementas, entre elas as facetas pedagógica, psicológica, psicolinguística, linguística e sociocultural. A Tabela 1, a seguir, foi organizada a partir do conteúdo das ementas, tendo como eixo as diferentes facetas consideradas para este estudo.

Tabela 1 - As facetas expressas nos conteúdos das ementas para a formação inicial do alfabetizador

\begin{tabular}{|c|c|c|c|}
\hline Facetas & Conteúdo destacado das ementas & $\begin{array}{c}\text { Frequência de } \\
\text { citações nas } \\
\text { ementas }\end{array}$ & $\begin{array}{l}\text { Frequência } \\
\text { de citações } \\
\text { nas facetas } \\
\end{array}$ \\
\hline \multirow{7}{*}{ Pedagógica } & Métodos de ensino & 56 & \multirow{7}{*}{171} \\
\hline & Prática e vivências pedagógicas & 50 & \\
\hline & Materiais didáticos & 22 & \\
\hline & Formação do professor & 16 & \\
\hline & Planejamento & 12 & \\
\hline & Documentos oficiais & 10 & \\
\hline & Avaliação & 5 & \\
\hline \multirow{4}{*}{ Sociocultural } & Alfabetização e letramento & 58 & \multirow{4}{*}{104} \\
\hline & Concepção de linguagem & 26 & \\
\hline & Gênero textual & 15 & \\
\hline & Literatura & 5 & \\
\hline \multirow{2}{*}{ Sociológica } & Histórico da alfabetização e do letramento & 74 & \multirow{2}{*}{80} \\
\hline & Analfabetismo & 6 & \\
\hline \multirow{3}{*}{ Linguística } & Leitura e escrita & 41 & \multirow{3}{*}{78} \\
\hline & Conceitos linguísticos & 34 & \\
\hline & Ortografia & 3 & \\
\hline \multirow[t]{2}{*}{ Psicológica } & $\begin{array}{l}\text { Aquisição da linguagem escrita/psicogênese da } \\
\text { escrita }\end{array}$ & 67 & \multirow[t]{2}{*}{70} \\
\hline & Dificuldade/Distúrbios da linguagem & 3 & \\
\hline Psicolinguística & Relação entre pensamento e linguagem & 12 & 12 \\
\hline Sociolinguística & Variação linguística & 11 & 11 \\
\hline
\end{tabular}

Fonte: As autoras, 2019. 
Os conteúdos localizados nas ementas das disciplinas relacionadas às diferentes facetas foram mapeados e organizados no Quadro 2, a seguir.

\title{
Quadro 2: Conteúdos das ementas organizados por facetas da alfabetização
}

\begin{abstract}
FACETA PEDAGÓGICA
a) Métodos de ensino: metodologias de alfabetização e letramento; processos de alfabetização e alternativas metodológicas; métodos, processos e habilidades requeridas do professor; percurso das metodologias de alfabetização; análise dos métodos de alfabetização; b) Práticas/vivências pedagógicas: diferentes concepções da língua escrita e suas implicações para a prática pedagógica; prática pedagógica no ensino da língua escrita; sistematização de conteúdos, atitudes e capacidades relacionadas às práticas de leitura e escrita; articulação teoria e prática no processo de alfabetização; práticas linguístico-discursivas e formação do leitor e do escritor; práticas de alfabetização e letramento; entre outros; c) Materiais didáticos: elaboração coletiva de materiais didáticos variados; materiais didáticos destinados à alfabetização; estudo e análise de recursos didáticos; propostas de ensino para a sistematização de projetos de leitura e escrita e elaboração de material didático conforme cada faixa etária; d) Planejamento: planejamento e sistematização de proposta de ensino direcionada à alfabetização; planejamento das formas de intervenção e organização progressiva do processo de aquisição da escrita; análise das propostas para o ensino das crianças em fase de alfabetização, procurando conciliar, de acordo com o cotidiano escolar, estruturando diversas formas e projetos de alfabetização; e) Avaliação: processos de avaliação e organização do ensino; o erro no processo de construção do conhecimento. Os elementos formação do professor alfabetizador e documentos oficiais foram citados pontualmente nas ementas, os últimos referem-se aos Parâmetros Curriculares Nacionais.
\end{abstract}

\section{FACETA SOCIOCULTURAL}

a) Alfabetização e letramento; b) Concepção de linguagem: linguagem, sociedade, cultura, discurso e ensino de língua; relação linguagem, cultura, sujeito e ensino da língua; concepção de escrita como textualidade; linguagem, definições e conceitos; linguagem enquanto produto e produtor de cultura; linguagem oral, escrita, visual, sonora, expressiva; linguagem e conhecimento; a linguagem enquanto sistema simbólico, representativo das interações humanas; c) Gênero textual: a importância dos estudos de diversos tipos de gêneros textuais para a aquisição da alfabetização, incluindo textos não escolares; estudo, análise, pesquisa e organização de elementos que caracterizam a construção e a apropriação dos processos de produção e interpretação textuais, em seus vários sistemas; importância da leitura e da escrita de gêneros textuais diversos e do uso de portadores sociais de texto; d) Literatura: o trabalho com a literatura infantil no decorrer do processo de alfabetização; o uso da biblioteca escolar; a formação do aluno leitor; o texto literário na alfabetização e contribuição das várias linguagens e dos estilos na literatura infantil para o processo de alfabetização e letramento no contexto da educação infantil e dos anos iniciais do ensino fundamental; a leitura, escrita e oralidade na infância.

\section{FACETA SOCIOLÓGICA}

Analfabetismo e histórico da alfabetização e letramento, contemplando: dimensões históricas da alfabetização; abordagem histórica da alfabetização no contexto educacional brasileiro; história da escrita e da leitura; o ensino da alfabetização e suas interfaces com o letramento: contextualização histórica da área de alfabetização, entre outros.

\section{FACETA LINGUÍSTICA}

a) Leitura e escrita: relações entre escrita e oralidade; ensino e aquisição da leitura e escrita por meio de produções textuais; concepções de leitura e escrita à luz da psicogênese e letramento; b) Conceitos linguísticos: conceitos linguísticos básicos (principalmente de fonética e fonologia), as características do sistema alfabético; consciência metalinguística (fonológica, sintática e semântica); c) Ortografia: diferentes tipos de erros e possibilidades de superação; ensino da ortografia da língua portuguesa.

\section{FACETA PSICOLÓGICA}

a) Aquisição da linguagem escrita/psicogênese da escrita: concepções teóricas de aquisição e desenvolvimento da linguagem escrita; o processo de construção/aquisição da leitura e da escrita; alfabetização como processo de construção: Piaget, a psicogênese e as propostas de Emília Ferreiro; teorias de aquisição da linguagem oral; concepções teóricas de aquisição e desenvolvimento da linguagem escrita; processos cognitivos subjacentes à compreensão do sistema de escrita; contribuições da linguística e da psicologia cognitiva; relações entre pensamento, linguagens e afetividade; processos de desenvolvimento humano e construção da linguagem e pensamento: o papel da linguagem no processo de 
construção de estruturas mentais superiores; b) Dificuldade/distúrbios da linguagem: abordagens para a superação das dificuldades na apropriação da linguagem escrita; abordagem dos distúrbios da linguagem. FACETA PSICOLINGUÍSTICA ${ }^{10}$

A relação pensamento e linguagem na aquisição da leitura e da escrita; a relação entre pensamento e linguagem na perspectiva de Vygotsky; convergências e diferenças entre Piaget e Vygotsky e sua repercussão na alfabetização.

\section{FACETA SOCIOLINGUÍSTICA}

Variação linguística: diversidade linguística de grupos sociais; preconceito linguístico e a hierarquização das diferentes línguas e dos diferentes falares no Brasil e no mundo; alfabetização e letramento em línguas maternas e o não apagamento das minorias étnico-linguísticas; implicações das variações linguísticas e da linguística textual no processo de alfabetização; a diversidade da língua portuguesa enfocando as abordagens da sociolinguística e da dialectologia, com ênfase na diferenciação dialetal do português brasileiro.

Fonte: Baseado nos excertos das ementas de Alfabetização. Organização: As autoras, 2020.

A frequência de citações de conteúdos nas ementas, conforme o Gráfico 1, possibilitou identificar a ênfase dada a cada uma das facetas.

Gráfico 1 - Frequência de citações de conteúdos referentes a cada faceta

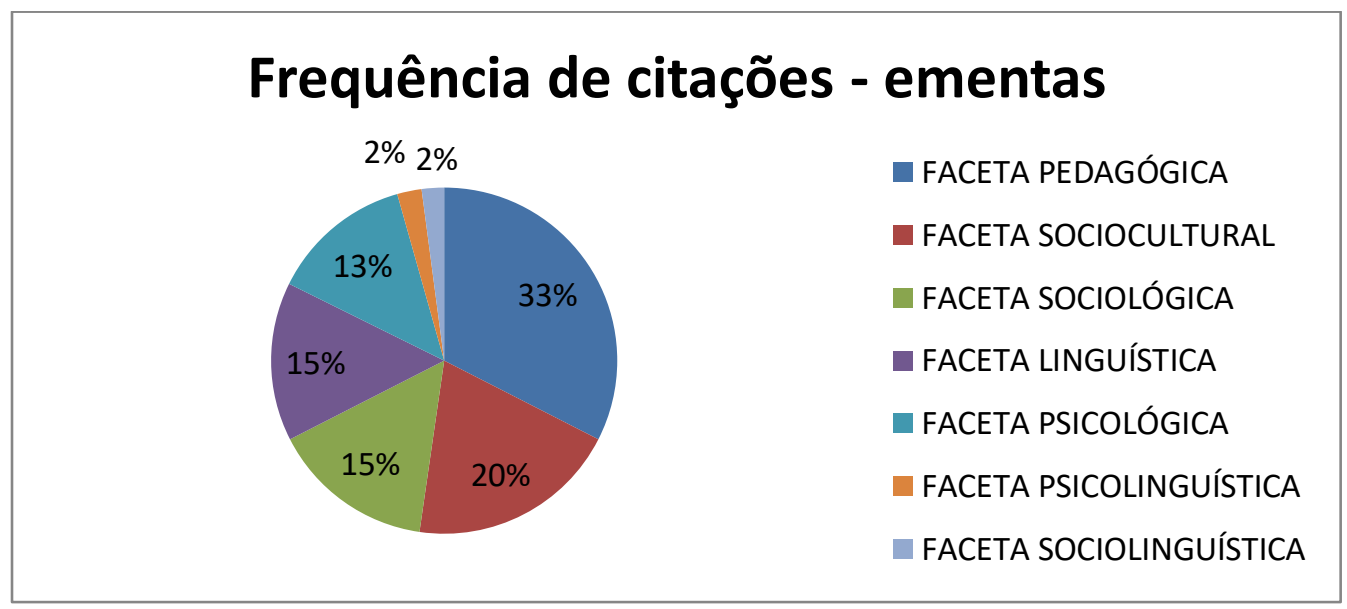

Fonte: As autoras, 2019

Ao analisarmos o conjunto das facetas abordadas nas ementas, notamos que os conteúdos mais abordados, com 171 indicações (33\%), referem-se à faceta pedagógica, seguida da faceta sociocultural, com 104 indicações (20\%). O resultado mostra uma nova tendência nos cursos de Pedagogia, que revela a abordagem dos métodos de ensino, das práticas e vivências pedagógicas aliadas aos estudos socioculturais, principalmente em relação à alfabetização e letramento, com 58 indicações. A inclusão e frequência da faceta sociocultural significa um avanço na discussão ampla do processo de alfabetização, no sentido do uso competente da leitura e da escrita em práticas sociais.

A faceta sociológica, com 80 indicações (15\%), revela que, principalmente, a abordagem da história da alfabetização e do letramento é muito presente nos cursos de Pedagogia (74 citações). No entanto, é ínfimo o estudo de temas referentes ao analfabetismo e as suas 
relações com a alfabetização e escolarização, pois foram encontradas apenas 6 indicações, o que fragiliza a compreensão de questões políticas, econômicas e ideológicas do fenômeno educativo intervenientes nas práticas de alfabetização e letramento.

A faceta linguística, com 78 citações (15\%), expressa em conteúdos relacionados à leitura e à escrita, a conceitos linguísticos voltados às características fonético-fonológicas da língua e ao ensino da ortografia, tem espaço semelhante à faceta sociológica e à faceta psicológica, com 70 menções $(13 \%)$, presente principalmente com os estudos da aquisição de linguagem escrita e a psicogênese da escrita. Os resultados mostram que ambas as facetas, a psicológica e a linguística, estão presentes em ementas dos 70 cursos de Pedagogia do Brasil, alterando a tendência cognitivista, discutida por Soares (2004), quando, segundo a autora, "a faceta psicológica obscureceu a faceta linguística da alfabetização, causando a 'desinvenção' da alfabetização".

A ênfase do último livro de Soares (2016) reincide sobre a explicitação da faceta linguística da alfabetização na tentativa de esclarecer que a alfabetização necessita de ensino direto e explícito de conteúdos relacionados ao funcionamento linguístico da modalidade escrita da língua. Isso não significa a volta à questão dos métodos, como podem supor alguns que defendem o resgate do método fônico nas escolas, e sim o alerta de que o processo de alfabetização exige uma multiplicidade de conhecimentos de origens variadas, entre eles, os conhecimentos da Linguística em suas diferentes áreas (Fonética e Fonologia, Sociolinguística, Linguística Textual, Psicolinguística, Pragmática, entre outras), da Psicologia e dos estudos socioculturais (como os estudos dos letramentos), além das questões pedagógicas, políticas, sociais.

Os estudos das facetas psicolinguística e sociolinguística são os menos citados, com apenas $12(2 \%)$ e $11(2 \%)$ indicações, respectivamente, o que pode significar uma lacuna no conhecimento do professor sobre a relação entre pensamento e linguagem e o desenvolvimento cognitivo para a aquisição do sistema alfabético-ortográfico pela criança, associado às questões das variedades linguísticas e suas influências sobre o processo de alfabetização. Esse dado sugere outra investigação sobre disciplinas do curso de Pedagogia que contemplem esses conhecimentos, como é o caso da disciplina de Psicologia da Educação.

Com o objetivo de construir uma análise mais próxima do real, passamos para a análise das bibliografias, entendendo que estas podem apresentar novos elementos de análise, como também confirmar os dados categorizados, considerando os conteúdos das ementas.

\subsection{Análise das bibliografias}

O trabalho desenvolvido em cada disciplina, nos cursos de graduação, é organizado em programas de ensino que contemplam a ementa, os objetivos, conteúdos, o sistema de avaliação e a bibliografia, os quais devem apresentar uma coerência entre si. A bibliografia expressa a base teórica da organização da disciplina, e os autores referenciados as tendências e os estudos realizados na área. 
A análise das bibliografias objetiva investigar as facetas mais estudadas, como também possibilita observar as congruências e divergências com os dados obtidos na análise das ementas. A análise foi realizada com base em 68 diferentes referências bibliográficas, que acompanhavam as 97 ementas $^{11}$ de disciplinas relativas à alfabetização. As referências se repetiram com diferentes frequências, sendo que 29 delas foram mais citadas e 39, ou seja, mais da metade, foram citadas em menos de 5 disciplinas, sendo consideradas de baixa recorrência, por isso não são mencionadas nesta análise.

As 29 bibliografias $^{12}$, com no máximo 72 e no mínimo 5 citações em diferentes disciplinas dos 70 cursos de Pedagogia, foram relacionadas na Tabela 2, que mostra as obras agrupadas pelo conteúdo pertinente à faceta da alfabetização com a qual tem a maior aproximação e a frequência que é citada nas disciplinas. No entanto, fazemos a ressalva de que as obras podem contemplar, com ênfases diferentes, temas de estudo que compreendem mais de uma faceta da alfabetização, entre as quais listamos a pedagógica/política, sociológica, sociolinguística, linguística/psicolinguística, sociocultural e psicológica/psicolinguística.

Tabela 2: Bibliografia indicada nas disciplinas relativas à alfabetização - Licenciatura em Pedagogia

\begin{tabular}{|c|c|c|c|}
\hline Faceta & $\begin{array}{c}\text { Bibliografia indicada nas ementas de disciplinas } \\
\text { relativas à alfabetização }\end{array}$ & $\begin{array}{l}\text { Frequência } \\
\text { de citações }\end{array}$ & $\begin{array}{l}\text { Frequência } \\
\text { de citações } \\
\text { nas facetas }\end{array}$ \\
\hline \multirow{6}{*}{ SOCIOCULTURAL } & $\begin{array}{l}\text { 1. SOARES, Magda. Letramento: um tema em três } \\
\text { gêneros. Belo Horizonte: Autêntica, } 1998 \text {. }\end{array}$ & 55 & \multirow{6}{*}{113} \\
\hline & $\begin{array}{l}\text { 2. CARVALHO, Marlene. Alfabetizar e letrar: um } \\
\text { diálogo entre a teoria e a prática. Petrópolis, RJ: Vozes, } \\
1998 .\end{array}$ & 13 & \\
\hline & $\begin{array}{l}\text { 3. KLEIMAN, Angela. (Org.). Os significados do } \\
\text { letramento: uma nova perspectiva sobre a prática } \\
\text { social da escrita. Campinas, SP: Mercado de Letras, } \\
1995 \text {. }\end{array}$ & 12 & \\
\hline & $\begin{array}{llc}\text { 4. TFOUNI, Leda Verdiani. Letramento } & \text { e } \\
\text { alfabetização. São Paulo: Cortez, } 1995 . & \\
\end{array}$ & 12 & \\
\hline & $\begin{array}{l}\text { 5. ROJO, Roxane (org.). Alfabetização e Letramento: } \\
\text { perspectivas linguísticas. Campinas: Mercado de } \\
\text { Letras, } 1998 \text {. }\end{array}$ & 11 & \\
\hline & $\begin{array}{l}\text { 6. MONTEIRO, Maria Iolanda Alfabetização e } \\
\text { letramento na fase inicial da escolarização. São } \\
\text { Carlos: EdUFSCar, } 2002 \text {. }\end{array}$ & 10 & \\
\hline \multirow{4}{*}{$\begin{array}{l}\text { PSICOLÓGICA/ } \\
\text { PSICOLINGUÍSTICA }\end{array}$} & $\begin{array}{l}\text { 1. FERREIRO, Emília; TEBEROSKY, Ana. A } \\
\text { psicogênese da Língua Escrita. Porto Alegre: Artes } \\
\text { Médicas, } 1985 .\end{array}$ & 72 & \multirow{4}{*}{109} \\
\hline & $\begin{array}{l}\text { 2. TEBEROSKY, Ana. Aprendendo a escrever: } \\
\text { perspectivas psicológicas e implicações educacionais. } \\
\text { São Paulo: Ática, } 1995 \text {. }\end{array}$ & 14 & \\
\hline & $\begin{array}{l}\text { 3. VYGOTSKI, Lev Semyonovitch. Pensamento e } \\
\text { linguagem. São Paulo: Martins Fontes, } 1987 .\end{array}$ & 13 & \\
\hline & $\begin{array}{l}\text { 4. KATO, Mary Aizawa. O mundo da escrita: uma } \\
\text { perspectiva psicolinguística. São Paulo: Ática, } 1986 .\end{array}$ & 10 & \\
\hline
\end{tabular}




\begin{tabular}{|c|c|c|c|}
\hline \multirow{10}{*}{$\begin{array}{l}\text { PEDAGÓGICA/ } \\
\text { POLÍTICA }\end{array}$} & $\begin{array}{l}\text { 1. Parâmetros Curriculares Nacionais - Língua } \\
\text { Portuguesa-PCNs }\end{array}$ & 16 & \multirow{10}{*}{86} \\
\hline & $\begin{array}{l}\text { 2. GROSSI, Esther Pillar. Didática do Nível Pré- } \\
\text { Silábico. v. 1. Rio de Janeiro: Paz e Terra, } 1990 .\end{array}$ & 14 & \\
\hline & $\begin{array}{l}\text { 3. BARBOSA, José Juvêncio. Alfabetização e } \\
\text { Leitura. São Paulo: Cortez, } 1990 .\end{array}$ & 10 & \\
\hline & $\begin{array}{l}\text { 4. KRAMER, Sonia. Alfabetização, leitura e escrita - } \\
\text { Formação de professores em curso. São Paulo: Ática, } \\
1995 .\end{array}$ & 10 & \\
\hline & $\begin{array}{l}\text { 5. CURTO, Luís Maruny et al. Escrever e Ler: como } \\
\text { as crianças aprendem e como o professor pode ensiná- } \\
\text { las a escrever e a ler. v. 1. Porto Alegre: ARTMED, } \\
2000 \text {. }\end{array}$ & 8 & \\
\hline & $\begin{array}{l}\text { 6. FRANCHI, Eglê Pontes. Pedagogia da } \\
\text { alfabetização: da oralidade à escrita. São Paulo: } \\
\text { Cortez, } 1988 .\end{array}$ & 6 & \\
\hline & $\begin{array}{l}\text { 7. GERALDI, João Wanderley. O texto na sala de } \\
\text { aula: leitura e produção. São Paulo: Ática, } 1984 .\end{array}$ & 6 & \\
\hline & $\begin{array}{l}\text { 8. LERNER, Delia. Ler e escrever na escola: o real, o } \\
\text { possível e o necessário. Porto Alegre: Artmed Editora, } \\
2002 \text {. }\end{array}$ & 6 & \\
\hline & $\begin{array}{l}\text { 9. BATISTA, Antônio Augusto Gomes; VAL, Maria da } \\
\text { Graça Ferreira da Costa (orgs.). Livros de } \\
\text { Alfabetização e de Português: os professores e suas } \\
\text { escolhas. Belo Horizonte: CEALE/Autêntica, } 2004 \text {. }\end{array}$ & 5 & \\
\hline & $\begin{array}{l}\text { 10. GONTIJO, Cláudia Maria Mendes. Alfabetização: } \\
\text { a criança e a linguagem escrita. Campinas, SP: Autores } \\
\text { Associados, } 2002 \text {. }\end{array}$ & 5 & \\
\hline \multirow{4}{*}{ LINGUÍSTICA } & $\begin{array}{l}\text { 1. CAGLIARI, Luiz Carlos. Alfabetização } \\
\text { linguística. 11. ed. São Paulo: Scipione, } 1989 .\end{array}$ & 31 & \multirow{4}{*}{57} \\
\hline & $\begin{array}{l}\text { 2. SMOLKA, Ana Luiza B. A criança na fase inicial } \\
\text { da escrita: a alfabetização como processo discursivo. } \\
\text { 11. ed. São Paulo: Cortez, } 1985 \text {. }\end{array}$ & 13 & \\
\hline & $\begin{array}{l}\text { 3. MORAIS, Artur Gomes de; ALBUQUERQUE, } \\
\text { Eliana Borges Correia de; LEAL, T. F. (orgs.). } \\
\text { Alfabetização: apropriação do sistema de escrita } \\
\text { alfabética. Belo Horizonte: Autêntica, 2005. }\end{array}$ & 7 & \\
\hline & $\begin{array}{l}\text { 4. LEMLE, Miriam. Guia teórico do alfabetizador. } 6 . \\
\text { ed. São Paulo: Ática, } 1987 .\end{array}$ & 6 & \\
\hline \multirow{5}{*}{ SOCIOLÓGICA } & $\begin{array}{l}\text { 1. FREIRE, Paulo. A importância do ato de ler: em } \\
\text { três artigos que se completam. São Paulo: Cortez, } 1982 .\end{array}$ & 15 & \multirow{5}{*}{49} \\
\hline & $\begin{array}{l}\text { 2. GARCIA, Regina Leite. Novos olhares sobre a } \\
\text { alfabetização. São Paulo: Cortez, } 2001 \text {. }\end{array}$ & 14 & \\
\hline & $\begin{array}{l}\text { 3. MORTATTI, Maria do Rosário Longo. Os sentidos } \\
\text { da alfabetização. São Paulo: UNESP, } 2000 .\end{array}$ & 10 & \\
\hline & $\begin{array}{l}\text { 4. GRAFF, Harvey. Os labirintos da alfabetização. } \\
\text { Porto Alegre: Artes Médicas, } 1994 .\end{array}$ & 5 & \\
\hline & $\begin{array}{l}\text { 5. BRANDÃO, Carlos Rodrigues. O que é o método } \\
\text { Paulo Freire. 16. ed. São Paulo: Brasiliense, } 1990 .\end{array}$ & 5 & \\
\hline
\end{tabular}

Fonte: As autoras, 2019. 
Foi possível observar que, entre as 68 obras referenciadas, a maioria corresponde à produção de autores nacionais com tradição na pesquisa em alfabetização e/ou letramento, no Brasil. As três obras mais referenciadas são: "A psicogênese da Língua Escrita", das argentinas Emília Ferreiro e Ana Teberosky, com 72 indicações; "Letramento: um tema em três gêneros", de Magda Soares, com 55 indicações; e "Alfabetização e linguística", de Luiz Carlos Cagliari, com 31 indicações. Constatamos, no levantamento das obras mais referenciadas, que a abordagem cognitivista da alfabetização permanece como prioritária em relação ao estudo das demais facetas, considerando as indicações em todas as disciplinas dos cursos de Pedagogia analisados. No entanto, verificamos a presença significativa da faceta sociocultural e da faceta linguística da alfabetização, conforme Soares (2004) apontava para esta necessidade.

A faceta sociocultural está presente em $27 \%$ das obras indicadas nas disciplinas, possui 6 autores referenciados, sendo a obra de Magda Soares, "Letramento: um tema em três gêneros", citada 55 vezes, ou seja, 49\% das citações dessa faceta. Os demais autores, como Carvalho, Kleiman, Tfouni, Rojo, Monteiro, são citados de $11 \%$ a $9 \%$ entre as obras relacionadas aos conhecimentos da faceta sociocultural. $\mathrm{O}$ dado revela a presença do estudo das práticas e usos sociais e culturais da leitura e da escrita na sociedade, prioritariamente, na obra de Soares, em mais da metade dos programas de ensino. A predominância de citações de obras da faceta sociocultural confirma a grande difusão dos estudos do letramento nas últimas décadas e converge com o que foi observado na análise das ementas.

A faceta psicológica tem como fundamento a obra de Vygotsky "Pensamento e linguagem", referenciada em 13 disciplinas, isto é, em 12\% delas. Processos psicológicos necessários à aprendizagem da leitura e da escrita também são estudados por meio de autores que tratam da psicolinguística, tais como: "A psicogênese da Língua Escrita", de Ferreiro \& Teberosky, com 72 indicações, correspondendo a 66\% das citações; "Aprendendo a escrever", de Teberosky, com 14 indicações (13\%); e "No mundo da escrita: uma perspectiva psicolinguística", de Kato, com indicação em 10 disciplinas (9\%). Estes dados confirmam que as facetas psicológica e psicolinguística permanecem em evidência nos cursos de Pedagogia.

A faceta pedagógica/política é a que possui o maior número de obras referenciadas, mas, no máximo, em 14 e, no mínimo, em 5 disciplinas, entre as 97 ementas pesquisadas, o que revela que autores que subsidiam o estudo desta faceta estão presentes em menos de $20 \%$ dos cursos analisados. Os Parâmetros Curriculares Nacionais (PCNs) de Língua Portuguesa aparecem em 16 disciplinas, isto é, em 18\%, revelando que tem sido o principal documento oficial utilizado para embasar a prática pedagógica alfabetizadora do pedagogo. Sendo este um documento parametrizador nacional, pode sugerir o caráter prescritivo na formação.

A bibliografia mais referenciada (16\%), depois dos PCNs, é a "Didática do Nível PréSilábico", de Esther P. Grossi, que integra a didática, a linguística e a psicolinguística. A obra de Kramer, referenciada em 10 disciplinas (12\%), foi o único referencial encontrado que trata de questões da faceta política referente à formação do professor e suas implicações sobre o processo de alfabetização, sendo uma lacuna para a formação crítica do professor alfabetizador. O livro de Curto et al. "Escrever e Ler: como as crianças aprendem e como o 
professor pode ensiná-las a escrever e a ler" é citado em apenas 8 disciplinas (9\%); Barbosa, que trata da aprendizagem da leitura (10\%); Curto (9\%), Franchi, Geraldi, Lerner (7\%), Batista e Val, que voltam-se para o estudo dos livros de alfabetização e Língua Portuguesa, e Gontijo (6\%). Estes dados revelam a fragilidade de estudos relativos à prática pedagógica intencional e sistematizada em relação ao conteúdo e forma, isto é, a teoria e prática da alfabetização e letramento.

Portanto, embora seja a faceta mais citada nas ementas e com o maior número de obras citadas, não é uma faceta contemplada em todas as disciplinas, o que pode sugerir a ruptura entre as obras que tratam do caráter teórico da aprendizagem da escrita e as obras que tratam de seu ensino.

A abordagem da faceta linguística é encontrada em 4 obras referenciadas nas disciplinas, sendo "Alfabetização e linguística", de Cagliari, a mais citada, com 31 indicações, isto é, 54\% das citações de obras dessa faceta. Autores menos citados como Smolka com 23\% das citações; Morais; Albuquerque; Leal com 12\%; e Lemle com 11\% das citações demonstram a escassez de referenciais que contemplam os conhecimentos linguísticos, tão necessários para o ensino da língua escrita. Esses números são um contrassenso, pois as áreas que explicam o funcionamento da língua escrita, objeto da alfabetização, são pouco abordadas na formação. Soares (2016) demonstra grande preocupação com essa questão e enfatiza, em sua obra, conhecimentos da faceta linguística necessários à alfabetização. Dessa forma, a faceta linguística, com 57 referências indicadas, apenas 14\% das citações entre as facetas, confirma, assim como na análise das ementas (com 15\%), uma lacuna na formação do alfabetizador.

O estudo da faceta sociológica é indicado em 5 obras, com 49 citações, o que totaliza apenas $12 \%$ de frequência entre as demais facetas. A obra "A importância do ato de ler: em três artigos que se completam", de Paulo Freire, é a mais citada, presente em 15 disciplinas, isto é, $31 \%$ das citações da faceta sociológica. Os livros de Garcia e Mortatti vêm na sequência, com $29 \%$ e $20 \%$, respectivamente, das citações entre as obras de perspectiva sociológica. Com 10\% das citações temos as obras de Graff e Brandão. Constata-se a pouca atenção dada aos estudos que problematizam as condições sociais em que a alfabetização ocorre no Brasil, às dificuldades e propostas para melhorar a aprendizagem da alfabetização e letramento da população, isto é, seu uso nas práticas sociais como condição de cidadania.

Não foi relacionada nenhuma bibliografia específica de fundamento sociolinguístico, embora os temas relativos a diferenças culturais e linguísticas no processo de alfabetização e letramento, em algumas obras, sejam tratados pelos autores da linguística, como também os que abordam a faceta sociocultural. Portanto, embora sejam apresentados conteúdos da faceta sociolinguística nas ementas analisadas (2\%), essa perspectiva é pouco enfatizada nos cursos investigados.

Em síntese, na análise das bibliografias constata-se o predomínio de obras que fundamentam o estudo das facetas por ordem de citações. 
Gráfico 2 - Frequência das facetas nas bibliografias

\section{Frequência de citações - bibliografias}

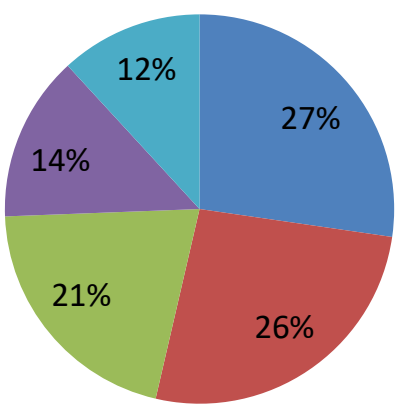

- FACETA SOCIOCULTURAL

- FACETA

PSICOLÓGICA/PSICOLINGUÍSTICA

- FACETA PEDAGÓGICA

- FACETA LINGUÍSTICA

- FACETA SOCIOLÓGICA

Fonte: As autoras, 2019.

Entendemos que o resultado indica a expressiva presença de bibliografias que discutem a faceta sociocultural, o que significa um avanço, seguida pela permanente evidência das facetas psicológica e psicolinguística. Os dados das bibliografias também mostram a presença secundária na formação do pedagogo das facetas pedagógica, linguística e sociológica, o que implica lacunas na preparação para a compreensão da base epistemológica teórico-prática referente ao ensino e à aprendizagem da leitura e da escrita e de processos sociais que influenciam e, por vezes, determinam os sucessos ou fracassos na alfabetização. Significa um desafio a ser enfrentado, pois a prática pedagógica requer conhecimentos articulados do campo da didática, dos métodos, avaliação, recursos e dos determinantes sociais e políticos externos à sala de aula e à escola.

Em acordo com Soares (2001, p. 103), formar o professor focando uma faceta do objeto que vai constituir a "área específica" em que vai atuar dá-se em "fragmentos", o que não contribuirá para identificá-la nem no sujeito nem no objeto com quem ele se defrontará em sala de aula, precisando recuperar sua totalidade.

\section{Considerações finais}

Compreendemos ser fundamental que o professor conheça a produção atualizada do conhecimento, a qual abrange todas as facetas da alfabetização, condição que não se efetiva ao se considerarem os resultados encontrados no levantamento dos conteúdos expressos nas ementas, bem como nas obras referenciadas nos 70 cursos de Pedagogia do Brasil. Constituise uma incógnita a relação teoria e prática nestes estudos, a relação com a realidade da escola pública, como também a atualidade da produção do conhecimento, pois as bibliografias não 
revelam a atualização dos referenciais. As denominações das disciplinas têm destacado aspectos que revelam o movimento construído ao longo dos últimos anos com priorização de aspectos específicos da faceta sociocultural. Os gráficos mostram, nas ementas, a priorização das facetas pedagógica e sociocultural, e nas bibliografias, das facetas sociocultural e psicológica/psicolinguística. A faceta linguística é indicada em apenas $15 \%$ das citações nas ementas e $14 \%$ nas bibliografias.

A atuação competente do professor alfabetizador requer o conhecimento do sistema alfabético-ortográfico da língua portuguesa, das teorias psicológicas e psicolinguísticas, mas, fundamentalmente, ter acesso à produção do conhecimento sobre alfabetização como direito humano, que tem se consolidado nas últimas décadas por meio das pesquisas sociolinguísticas, sociológicas, socioculturais e antropológicas-

No entanto, a atual Política Nacional de Alfabetização (PNA), instituída pelo Decreto $\mathrm{n}^{\circ}$ 9.765/2019, encaminha estratégias para formação e práticas pedagógicas embasadas especificamente na ciência cognitivista e na neurociência, com ênfase na aplicação do método fônico. Aderente ao projeto político-ideológico neoliberal ultraconservador, em curso, a PNA desconsidera avanços conquistados pela pesquisa no campo da alfabetização e da Pedagogia e apresenta problemas epistemológicos, pedagógicos e metodológicos que provocam retrocessos na formação de alfabetizadores, com consequências para a educação pública. A ênfase na faceta pedagógica baseada no método fônico e na faceta psicológica cognitivista baseada na neurociência fere o princípio da pluralidade de concepções e métodos que fundamentam a prática alfabetizadora e a atenção à diversidade sociocultural e de aprendizagem existentes nas salas de aula.

Dessa forma, os problemas de alfabetização no Brasil não serão superados pela adoção exclusiva de um método, como justifica a PNA, mas, sim, pela articulação de políticas educacionais que garantam a educação pública de qualidade, com priorização de recursos para engendrar avanços expressivos nos currículos, materiais, condições de trabalho e práticas pedagógicas. Este é o desafio ético-político a ser materializado na preparação de professores para o enfrentamento das desigualdades educacionais e efetivação da alfabetização como direito humano, demanda que necessita ser discutida no âmbito da formação de professores, nos cursos de Pedagogia.

\section{Notas}

1. Conforme Soares (2016, p. 33), entende-se por facetas "os componentes do processo de aprendizagem da língua escrita" que "se somam para compor o todo que é o produto desse processo: alfabetização e letramento."

2. Ver Soares e Maciel (2000).

3. Para Freitas (2007, p. 1220), a perspectiva da formação sócio-histórica dos educadores situa a formação no campo das suas lutas históricas, no entendimento de que os princípios da base comum nacional criam condições para a formação unitária dos educadores. A Associação Nacional pela Formação dos Profissionais da Educação, ANFOPE, desde 1983, delineia princípios para Base Comum Nacional, que se constitui em um conjunto de eixos norteadores da organização curricular, entendidos como princípios orientadores das condições de formação de todo o educador de modo a desenvolver, entre outros aspectos, uma sólida formação teórica e interdisciplinar no campo da educação; identificar eixos articuladores que garantam a unidade entre teoria e prática; assumir o compromisso social, político e ético com 
um projeto emancipador e transformador das relações sociais excludentes e com o processo de formação profissional, com fundamento na concepção sócio-histórica de educador (ANFOPE, 2008, p.11).

4. Ao nos referirmos às facetas da alfabetização, estamos considerando a alfabetização numa perspectiva de letramento.

5. A coleta foi realizada por Lidiane de Souza Leal durante sua participação no Programa Institucional de Bolsas de Iniciação Científica -UEPG, financiado pelo CNPq.

6. O termo e o conceito de letramento chegam ao Brasil na década de 80, tendo sua primeira aparição no livro No mundo da escrita: uma perspectiva psicolinguística, de Mary Kato (1986).

7. Diretrizes Curriculares Nacionais para o Ensino Fundamental de 9 anos, Resolução CNE/CB no 7/2010 expressa no "Art. 30 - Os três anos iniciais do Ensino Fundamental devem assegurar: I - a alfabetização e o letramento" (BRASIL, 2010).

8. As Diretrizes Curriculares Nacionais para a graduação em curso de Pedagogia, licenciatura, resulta de amplos debates desencadeados pelo movimento de educadores representados pelas entidades ANFOPE, ANPED, CEDES, ANPAE e FORUMDIR, que objetivaram contrapor a concepção do pedagogo generalista com a formação fragmentada em habilitações, em acordo com o Parecer do CFE 252/69, de perspectiva tecnicista que separava o pensar do fazer, a teoria da prática e que não contemplava como base de sua formação a preparação para a docência - o ser professor.

9. Resolução $\mathrm{CNE} / \mathrm{CP}^{\circ}{ }^{\circ}$ 2, de 1 de julho de 2015 define Diretrizes Curriculares para a formação inicial em nível superior (cursos de licenciatura, cursos de formação pedagógica para graduados e cursos de segunda licenciatura) e para a formação continuada, resultou de amplo debate entre entidades representativas de educadores e inovou ao conceber em uma diretriz a dimensão da formação inicial, continuada e valorização da carreira docente. No entanto, foi revogada pela Resolução CNE/CP n ${ }^{\circ}$ 2, de 20 de dezembro de 2019, que define as Diretrizes Curriculares Nacionais para a Formação Inicial de Professores para a Educação Básica e institui a Base Nacional Comum para a Formação Inicial de Professores da Educação Básica (BNC-Formação) que foi aprovada sem interlocução com as entidades representativas de educadores. Ambas não revogaram a Resolução CNE/CP nº1/2006, que define as Diretrizes Curriculares Nacionais para o curso de Pedagogia.

10. Muitas vezes, os conteúdos expressos nas ementas conjugam as facetas no estudo das questões relacionadas à escrita. Essa relação é bastante visível com as facetas psicológica e psicolinguística. Optamos por mantê-las separadas na análise das ementas por percebermos alguma especificidade de conteúdo. Entretanto, na análise das bibliografias as unimos. Se uníssemos as duas facetas, psicológica e psicolinguística, nesta análise, teríamos um número de 82 citações, o que faz com que ela seja mais citada nas ementas do que as facetas linguística e sociológica.

11. A maioria dos cursos de Pedagogia possuem mais de uma disciplina relacionada à alfabetização, por isso o número de 97 ementas de disciplinas é maior do que o número de 70 Projetos Pedagógicos de Curso.

12. A indicação do ano das obras corresponde à edição mais antiga dentre as referências bibliográficas encontradas nas ementas/disciplinas.

\section{Referências}

ANFOPE. Documento Final 14 Encontro Nacional - A ANFOPE e os desafios de um sistema nacional de formação de profissionais da educação. UNB, 2008. Disponível em: https://formacaoprofessordotcom.files.wordpress.com/2017/10/doc-final-xiv-encontro-nacional.pdf

BARDIN, L. Análise de conteúdo. São Paulo: Edições 70, 2010.

BRASIL. Conselho Nacional de Educação. Resolução CNE/CP nº1 de 15 de maio de 2006. Institui Diretrizes Curriculares Nacionais para o Curso de Graduação em Pedagogia, licenciatura. Diário Oficial da União, Brasília, DF, 16 de maio de 2006.

BRASIL. Resolução n ${ }^{\circ}$ 2, de $1^{\circ}$ de julho de 2015. Define as Diretrizes Curriculares Nacionais para a formação inicial em nível superior (cursos de licenciatura, cursos de formação pedagógica para graduados e cursos de segunda licenciatura) e para a formação continuada. Diário Oficial da União, Brasília, DF, 2 de julho de 2015. 
BRASIL. Resolução no 2, de 20 de dezembro de 2019. Define as Diretrizes Curriculares Nacionais para a Formação Inicial de Professores para a Educação Básica e institui a Base Nacional Comum para a Formação Inicial de Professores da Educação Básica (BNC-Formação). Diário Oficial da União, Brasília, DF, 15 de abril de 2019.

BRASIL. Decreto n 9.765, de 11 de abril de 2019. Institui a Política Nacional de Alfabetização. Diário Oficial da União, Brasília, DF, 11 de abril de 2019.

FREITAS, Helena Costa Lopes de. A (nova) política de formação de professores: a prioridade postergada. Educação e Sociedade, Campinas, v. 28, n. 100 - Especial, p. 1203-1230, out. 2007.

GATTI, Bernardete. Formação de professores no Brasil: características e problemas. Educação e Sociedade, Campinas, v. 31, n. 113, p. 1355-1379, out./dez. 2010.

GATTI, Bernardete. A Formação inicial de professores para a educação básica: pesquisas e políticas educacionais. Estudos em Avaliação Educacional, v. 25, n. 57, p. 24-54, 2014.

GATTI, Bernardete; NUNES, Marina Muniz Rossa (orgs.). Formação de professores para o ensino fundamental: Estudo de currículos das licenciaturas em Pedagogia, Língua Portuguesa, Matemática e Ciências Biológicas. São Paulo: Fundação Carlos Chagas, 2009.

LOTFI, Maria do Carmo Ferreira. Alfabetização. Where and as if it forms the alfabetizador professor? 2011. 114 f. Dissertação (Mestrado em Educação) - Universidade Nove de Julho, São Paulo, 2011.

NORNBERG, Marta; JÄGER, Josiane Jarline; SOUTO, Luiza Kerstner. Concepções e princípios para o planejamento do ensino: a perspectiva de professoras orientadoras de estudo. Currículo sem Fronteiras, v. 19, n. 1, p. 335-357, 2019. Disponível em: http://www.curriculosemfronteiras.org/vol19iss1articles/ nornberg-jager-souto.html. Acesso em: 01 jul. 2020.

MORTATTI, Maria do Rosário Longo. História dos métodos de alfabetização no Brasil. In: SEMINÁRIO NACIONAL ALFABETIZAÇÃO E LETRAMENTO EM DEBATE, 2006, Anais... Brasília, DF: Departamento de Políticas de Educação Infantil e Ensino Fundamental, 2006. v. 1, p. 1-16. Disponível em: http://portal.mec.gov.br/seb/arquivos/pdf/Ensfund/alf_mortattihisttextalfbbr.pdf. Acesso em: 01 jul. 2020.

PICCOLI, Luciana. Como formar um professor alfabetizador no curso de Pedagogia? Discussões sobre a formação inicial nas Universidades Federais da Região Sul do Brasil. Revista Brasileira de Alfabetização/Associação Brasileira de Alfabetização - ABAlf, Vitória, v. 1, n. 1, p. 132-154, jan./jun. 2015.

PIMENTA, Selma Garrido; PINTO, Umberto de Andrade; SEVERO, José L.R. de L. A Pedagogia como lócus de formação profissional de educadores(as): desafios epistemológicos e curriculares. Revista Práxis Educativa, v. 15, p. 1-20, 2020. Disponível em: https://www.revistas2.uepg.br/index.php/ praxiseducativa/article/view/15528 Acesso: 01 jul. 2020.

ROJO, Roxane. Letramentos múltiplos, escola e inclusão social. São Paulo: Parábola Editorial, 2009.

ROMANOWSKI, Paulin Joana. Conhecimentos pedagógicos nos cursos de licenciatura e a base comum de formação de professores. In: ROMANOWSKI, Paulin Joana; MARTINS, Pura Lúcia Oliver; CARTAXO, Simone Regina Manosso (orgs.). Práticas de formação de professores: da Educação Básica a Educação Superior. Curitiba: PUCPR, 2016. p. 47-69.

SAVIANI, Dermeval. Formação de professores no Brasil: dilemas e perspectivas. Poíesis Pedagógica, v.9, n.1 jan./jun. 2011.

SCHEIBE, Leda. Diretrizes curriculares para o curso de Pedagogia: trajetória longa e inconclusa. Cadernos de Pesquisa, v. 37, n. 130, jan./abr. 2007.

SOARES, Magda. As muitas facetas da alfabetização. Cadernos de Pesquisa, São Paulo, v.52, p. 19-24, fev. 1985.

SOARES, Magda. Letramento: um tema em três gêneros. Belo Horizonte: Autêntica, 1998. 
SOARES, Magda. As pesquisas nas áreas específicas influenciando o curso de formação de professores. In: ANDRÉ, Marli Eliza D. A. O papel da pesquisa na formação e na prática dos professores. 9. ed. São Paulo: Papirus, 2001.

SOARES, Magda. Letramento e Alfabetização: as muitas facetas. Revista Brasileira de Educação, São Paulo, n.25, p.5-17, jan./abr. 2004.

SOARES, Magda. Práticas de letramento e implicações para a pesquisa e para políticas de alfabetização e letramento. In: MARINHO, Marildes; CARVALHO, Gilcinei Teodoro. Cultura escrita e letramento. Belo Horizonte: UFMG, 2010. p. 54-67.

SOARES, Magda. Alfabetização: a questão dos métodos. São Paulo: Contexto, 2016.

SOARES, Magda. Alfabetização e letramento. 7. ed. São Paulo: Contexto, 2017.

SOARES, Magda Becker; MACIEL, Francisca. Alfabetização. Brasília: MEC/Inep/Comped, 2000. 173 p.: tab. (Série Estado do Conhecimento, ISSN 1518-3653; n. 1).

\section{Correspondência}

Simone Regina Manosso Cartaxo: Doutora em Educação. Professora do Departamento de Pedagogia e do Programa de Pós-Graduação em Educação da Universidade Estadual de Ponta Grossa, linha de pesquisa Ensino e Aprendizagem. Coordena o Grupo de Estudos e Pesquisa Didática e Formação Docente GEPEDIDO. Desenvolve pesquisas sobre formação de professores, formação do alfabetizador e práticas pedagógicas. Universidade Estadual de Ponta Grossa - UEPG

E-mail: simonemcartaxo@hotmail.com

Giselle Cristina Smaniotto: Doutora em Linguística. Professora do Departamento de Pedagogia da Universidade Estadual de Ponta Grossa. Atua na área de Alfabetização e Língua Portuguesa e desenvolve pesquisas sobre a formação docente e o ensino e a aprendizagem das práticas de linguagem na Educação Básica e Superior.

E-mail: gisellesmaniotto@yahoo.com.br

Maria Iolanda Fontana: Doutora em Educação. Professora do Programa de Pós-Graduação em Educação da Universidade Tuiuti do Paraná (UTP), na linha práticas pedagógicas: elementos articuladores. Membro do Núcleo de Pesquisa em Educação do Campo, Movimentos Sociais e Práticas Pedagógicas (NUPECAMP/UTP). Desenvolve pesquisas, principalmente, sobre políticas e práticas de formação de professores, curso de Pedagogia e Educação do Campo.

E-mail: maria.iolanda.fontana@gmail.com

Texto publicado em Currículo sem Fronteiras com autorização das autoras 